\title{
A Short Essay Proposing a Test for Unlawful Executive Legislation
}

\author{
BENJAMIN M. FLOWERS*
}

This short essay addresses the following question: what test should courts use to identify actions by the federal government's executive branch that are unlawfully legislative in nature?

I will attempt to answer that question from an originalist perspective. And so I will begin by explaining the problem from an originalist perspective. Most originalists, I think, would agree with the following three propositions. First, the United States Constitution vests the entirety of the federal government's legislative power exclusively in Congress. ${ }^{1}$ Second, the government exercises legislative power when it makes generally applicable rules that bind private conduct. $^{2}$ Third, the executive branch very often promulgates regulations through which it makes generally applicable rules that bind private conduct.

Anyone who accepts those premises - and again, I suspect most originalists would - must conclude that many of the regulations promulgated by the executive branch, on an almost-daily basis, are unconstitutional. Such regulations govern many aspects of American life, from the mundane (the circumstances in which a pet-food manufacturer must include serving sizes on its packaging) ${ }^{3}$ to the significant (the operation of electricity-generating facilities). ${ }^{4}$

Despite their agreeing on the problem, and on the degree to which the problem bears on American life, originalists have not yet settled on a solution. They have not, in other words, found a judicially administrable test for deciding which regulations are unconstitutionally legislative in nature. Developing such a test is harder than it might seem because the executive branch may constitutionally promulgate rules and policies that look a lot like legislation. While "the making of laws is entirely" a job for the legislature, "the manner, time, and circumstances of putting those laws in execution must frequently be left to the discretion of the executive magistrate." And so the executive power, which the Constitution vests in the President, has long been understood to

* Solicitor General of Ohio. The views expressed in this article are mine alone. Any errors are too.

${ }^{1}$ U.S. CONST. art. I, $\S 1$ ("All legislative Powers herein granted shall be vested in a Congress of the United States ....").

2 Dep't of Transp. v. Ass'n of Am. R.R., 135 S. Ct. 1225, 1242-43 (2015) (Thomas, J., concurring in the judgment); PHILIP HAMBURGER, Is ADMINISTRATIVE LAW UNLAWFUL? 84 (2014); Michael W. McConnell, The President Who Would Not Be King 110-11 (2020).

${ }^{3}$ Labeling of Animal Food With Number of Servings, 21 C.F.R. $§ 501.8(a)$ (2020).

${ }^{4}$ See, e.g., Standard for Particulate Matter (PM), 40 C.F.R. $\$ 60.420$ (2020).

5 MCCONNELL, supra note 2, at 111 (quoting 1 BLACKSTONE's COMMENTARIES 26061 (St. George Tucker ed., Rothman Reprints 1969) (1803)). 
include authority to announce policies regarding how a law will be executed. Therein lies the trouble: how does one distinguish between a regulation that (permissibly) declares the "manner" in which a law will be executed and a regulation that (impermissibly) is in reality an altogether new "law"?

The courts have not yet provided a satisfactory answer. For example, while the "non-delegation doctrine" purports to bar Congress from giving the executive branch legislative authority, the test for an unlawful delegation is so lax that the doctrine, in practice, prohibits nothing at all. According to the Supreme Court, Congress impermissibly delegates legislative authority to the Executive only when it passes a law that contains no "intelligible principle to which the person or body authorized to [act] is directed to conform." $"$ That standard is, to put it mildly, "not demanding."" In applying it, the Court has "over and over upheld even very broad delegations." It has "approved delegations to various agencies to regulate in the "public interest[;]" it has "sustained authorizations for agencies to set 'fair and equitable' prices and 'just and reasonable' rates[;]"10 and it once "affirmed a delegation to an agency to issue whatever air quality standards are 'requisite to protect the public health." "11 Most recently, the Supreme Court invoked the intelligible-principle test to uphold a law that empowered the U.S. Attorney General to "specify the applicability of" a sex-offender-registry law "to sex offenders convicted before" the law's enactment, and "to prescribe rules for the registration of any such sex offenders." "12

As these examples show, the intelligible-principle test will be of no help in placing limits on executive lawmaking. But the test will never go away unless someone proposes something better. The purpose of this little essay is to suggest one better option - a test that is both judicially administrable and grounded in the Constitution's text.

Here is my suggestion: a regulation promulgated by the executive branch qualifies as an unconstitutional exercise of legislative power if it purports to set standards for enforcing, against private conduct, a law that would otherwise be too vague to apply. A law is "too vague to apply," for my purposes, if it "fails to give ordinary people fair notice of the conduct it punishes." 13 If a statute fails to give fair notice, any regulation purporting to define the manner in which that

${ }^{6}$ Whitman v. Am. Trucking Ass'ns, Inc., 531 U.S. 457, 472 (2001) (quoting J. W. Hampton, Jr., \& Co. v. United States, 276 U.S. 394, 409 (1928)).

${ }^{7}$ Gundy v. United States, 139 S. Ct. 2116, 2129 (2019) (plurality).

${ }^{8} \mathrm{Id}$.

${ }^{9} I d$. (citing Nat'l Broad. Co. v. United States, 319 U.S. 190, 216 (1943); N.Y. Cent. Sec. Corp. v. United States, 287 U.S. 12, 24 (1932)).

${ }^{10}$ Id. (citing Yakus v. United States, 321 U.S. 414, 422, 427 (1944); Fed. Power. Comm'n v. Hope Nat. Gas Co., 320 U.S. 591 (1944)).

${ }^{11}$ Id. (citing Whitman, 531 U.S. at 472).

${ }^{12}$ Id. at 2122; id. at 2130-31 (Alito, J., concurring in the judgment); see also 34 U.S.C. $\S 20913(d)$.

13 Johnson v. United States, 576 U.S. 591, 595 (2015). 
statute will be applied to private conduct qualifies as executive legislation and is therefore unconstitutional.

This test is both judicially administrable and consistent with the Constitution's prohibition of executive lawmaking. We know it is judicially administrable because it turns on a definition of "vagueness" that is identical to the definition the courts already apply when assessing unconstitutional vagueness. The test is consistent with the prohibition on executive lawmaking because it forbids only those regulations that make generally applicable rules of conduct (which is to say, legislation) where none exists already. "Vague statutes have the effect of delegating lawmaking authority to the executive." 14 After all, if a statute is so vacuous or unclear or incomprehensible that it provides no fair notice of its requirements, then it is the equivalent of an inkblot or a string of gibberish, which is the equivalent of no law whatsoever. ${ }^{15}$ And a regulation purporting to carry into effect a statute that is no law whatsoever is, in fact, legislation on its own; when "the legislation" Congress passes is in reality an "unfinished law which the administrative body must complete before it is ready for application[,]"16 the administrative body is charged with making law. The agency in these circumstances is legislating, not merely defining "the manner, time, and circumstances of putting" a congressionally enacted statute "in execution." 17 That is why, as Justice Gorsuch recognized in his recent Gundy dissent,

$[\mathrm{M}]$ ost any challenge to a legislative delegation can be reframed as a vagueness complaint: A statute that does not contain "sufficiently definite and precise" standards "to enable Congress, the courts, and the public to ascertain" whether Congress's guidance has been followed at once presents a delegation problem and provides impermissibly vague guidance to affected citizens. ${ }^{18}$

Two clarifications before moving on. First, I am not advocating for incorporating the vagueness doctrine into the non-delegation doctrine. I am borrowing the standard only because it is a good one for determining when a law - whether criminal or civil - is a "law" in any meaningful sense. Second, I am proposing this test for assessing the constitutionality only of regulations that govern the legality of private conduct. I take no position on whether the test applies to other types of regulations. For example, this essay does not propose a test for assessing the constitutionality of regulations that govern the conduct of executive officers or that dictate the nature of agency proceedings, even if those

\footnotetext{
${ }^{14}$ Nathan S. Chapman \& Michael W. McConnell, Due Process as Separation of Powers, 121 YALE L.J. 1672, 1806 (2012).

${ }^{15}$ Cf. Frank H. Easterbrook, Statutes' Domains, 50 U. CHI. L. REV. 533 (1993).

${ }^{16}$ Fed. Trade Comm'n v. Ruberoid, Inc., 343 U.S. 470, 485 (1952) (Jackson, J., dissenting).

${ }^{17}$ MCCONNELL, supra note 2, at 111 (quoting 1 BLACKSTONE's COMMENTARIES 26061 (St. George Tucker ed., Rothman Reprints 1969) (1803)).

18 Gundy v. United States, 139 S. Ct. 2116, 2142 (2019) (Gorsuch, J., dissenting) (quoting Yakus v. United States, 321 U.S. 414, 426 (1944)).
} 
regulations might affect or bind private actors in their interactions with the government.

Now let me illustrate my test with a concrete example. Imagine a law that requires the President (or some subordinate) to set "just and reasonable rates" for a particular industry and that penalizes those who charge higher-thanallowable rates. Now suppose the President declares a rate: $\$ 10$ per unit. A company charges a higher rate, and the United States charges that company with a crime or civil offense. That company should be able to argue, as a defense, that the rule under which it is being penalized is unconstitutional because it is "legislation" promulgated by the executive branch. And how do we know the rule is unconstitutional? Because the statute itself is so lacking in meaning regarding permissible rates that anyone charged with violating it in fact violates the regulation, not the statute. So, it is the regulation, not the rule, that proscribes certain conduct. When the executive branch promulgated the regulation, it impermissibly made law.

One might object that my test is inconsistent with the Supreme Court's precedent. ${ }^{19}$ Indeed it is. The same will likely be true of any other test that restores, to any degree, the Constitution's original meaning in this area. I will leave for another day — or, more likely, for other people — the question whether stare decisis ought to stand in the way of enforcing the Constitution's limits on executive legislation.

${ }^{19}$ See supra notes 6-12 and accompanying text (discussing the intelligible-principle test). 